\section{IRRIGATION SCHEDULING FOR AGRICULTURE IN THE UNITED STATES: THE PROGRESS MADE AND THE PATH FORWARD}

\author{
S. Taghvaeian, A. A. Andales, L. N. Allen, I. Kisekka, S. A. O’Shaughnessy, \\ D. O. Porter, R. Sui, S. Irmak, A. Fulton, J. Aguilar
}

Beyond 2020,

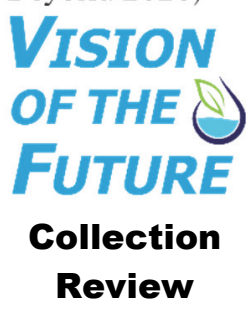

\begin{abstract}
HighLights
- The progress made in agricultural irrigation scheduling in the past ten years and the current challenges are discussed.

- The main scientific scheduling strategies are based on soil water status, plant characteristics, and crop modeling.

- Challenges include large time and data requirements and availability of decision support systems.

- Opportunities include integration of scheduling strategies and demonstrating their effectiveness through local studies.
\end{abstract}

ABSTRACT. Irrigation scheduling is the process of determining the appropriate amount and timing of water application to achieve desired crop yield and quality, maximize water conservation, and minimize possible negative effects on the environment, such as nutrient leaching below the crop root zone. Effective irrigation scheduling has been shown to save water, save energy, and help agricultural producers achieve improved yields and quality. However, scientific irrigation scheduling methods generally have remained limited to mostly research applications with relatively low adoption by irrigators. There are several main approaches to irrigation scheduling, including those based on soil water status, plant characteristics, and/or crop modeling. Each of these approaches has advantages as well as limitations and sources of uncertainty and variability, depending on application conditions. This article summarizes progress made in the U.S. in each of the main scheduling approaches in the past ten years (since the 2010 Decennial Irrigation Symposium) and existing challenges and opportunities that should be considered moving forward. This article is intended to guide future research and extension projects in improving adoption of scientific irrigation scheduling approaches.

Keywords. Computer modeling, Plant characteristics, Soil water status.

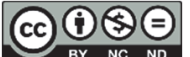

The authors have paid for open access for this article. This work is licensed under a Creative Commons AttributionNonCommercial-NoDerivatives 4.0 International License https:/creative commons.org/licenses/by-nc-nd/4.0/

Submitted for review in May 2020 as manuscript number NRES 14110 approved for publication as a Review Article and as part of the National Irrigation Symposium 2020 Collection by the Natural Resources \& Environmental Systems Community of ASABE in July 2020.

Mention of company or trade names is for description only and does not imply endorsement by the USDA. The USDA is an equal opportunity provider and employer.

The authors are Saleh Taghvaeian, Associate Professor, Department of Biosystems and Agricultural Engineering, Oklahoma State University, Stillwater, Oklahoma; Allan A. Andales, Professor, Department of Soil and Crop Sciences, Colorado State University, Fort Collins, Colorado; L. Niel Allen, Associate Professor, Department of Civil and Environmental Engineering, Utah State University, Logan, Utah; Isaya Kisekka, Associate Professor, Department of Land, Air, and Water Resources and Department of Biological and Agricultural Engineering, University of California, Davis, California; Susan A. O'Shaughnessy, Research Agricultural Engineer, USDA-ARS Conservation and Production Research Laboratory, Bushland, Texas; Dana O. Porter, Professor, Department of Biological and Agricultural Engineering, Texas A\&M AgriLife Extension, Lubbock, Texas; Ruixiu Sui, Research Agricultural Engineer, USDA-ARS Sustainable Water Management Research Unit, Stoneville, Mississippi, Suat Irmak, Professor, Department of Biological Systems Engineering, University of Nebraska, Lincoln, Nebraska; Allan Fulton, Irrigation and Water Resources Advisor, University of California Cooperative Extension, Red Bluff, California; Jonathan Aguilar, Associate Professor, Department of Biological and Agricultural Engineering, Kansas State University, Garden City, Kansas. Corresponding author: Saleh Taghvaeian, 111 Agricultural Hall, Oklahoma State University, Stillwater, OK 74078; phone: 405-744-8395; e-mail: saleh.taghvaeian@okstate.edu.
I rrigation scheduling is defined as the scientific process of determining and optimizing the timing and amount of irrigation applications in order to meet specific management goals, generally to prevent yield-limiting crop water stress. However, irrigation also has other objectives, such as application of fertilizers and other chemicals (fertigation/chemigation), leaching of salts, and cooling or warming of the microclimate. Effective irrigation scheduling helps to optimize profit while minimizing potential negative effects on the environment. As droughts, unpredictable rainfall patterns, and shortages in reliable water supplies become more common across the U.S. and globally, irrigation scheduling strategies are vital to adapt to climate change vulnerability and sustain irrigated crop production (Irmak, 2015; Steiner et al., 2018). Furthermore, as irrigated land area continues to expand eastward across the U.S., the transfer of successful irrigation scheduling strategies, technologies, and lessons learned will be key to facilitating best management practices for crop water management on a national scale.

According to surveys conducted by the USDA, irrigated farms and area in the U.S. increased by approximately $1 \%$ from 2013 to 2018, and the total amount of water used in 2018 was 5.8\% less (USDA, 2019). From the same data source, the percentage of farms reporting use of any type of irrigation scheduling method increased by $1 \%$. Considering 
this small increase in adoption, it is worth reviewing the type of irrigation scheduling methods currently in use, as well as the future research that will open new opportunities for producers to improve irrigation scheduling techniques and strategies. However, it should be noted that promoting the adoption of scientific irrigation scheduling methods is not solely dependent on appropriate, timely, and applied-research projects. In the Mediterranean region, Giannakis et al. (2016) mentioned several other factors that impact adoption of irrigation scheduling decision support systems, including userfriendliness of developed strategies, water pricing, and national/regional policies. A survey conducted by Lichtenberg et al. (2015) in the U.S. highlighted the importance of economic benefits and found that greenhouse and nursery producers who were willing to implement wireless sensor networks for irrigation scheduling anticipated an appreciable return on investment. Based on the long-term experiences of the Nebraska Agricultural Water Management Network (NAWMN), Irmak et al. (2010) stated that technology adoption in irrigation is strongly related to attributes of the technologies, such as being economical, durable, easy to use, straightforward in terms of data interpretation, and based on scientific research. For technologies with these attributes, the potential for adoption is great, especially when adoption efforts are coupled with coordinated and carefully designed and delivered educational/extension programs. Rudnick et al. (2020) provided examples of several innovative extension programs in the U.S. and argued that extension methods that rely on experiential learning, develop user networks, and collaborate with industry can increase the adoption of scientific irrigation scheduling.

Several previous studies have reviewed irrigation scheduling strategies, their features, and their advantages and caveats. At the last Decennial Irrigation Symposium, Henggeler et al. (2010) reported on irrigation schedulers that had been developed and used during the ten years prior to 2010 . They also listed eleven computer-based schedulers that relied on local or national weather data and provided irrigation management recommendations for a wide range of crops and states/regions. At the same conference, Hillyer and Robinson (2010) outlined the requirements for the next generation of irrigation schedulers. They argued that future schedulers should:

- Serve as optimization tools and allow full-season forecasting of the impact of variable irrigation management and their economic consequences.

- Support deficit irrigation scheduling as freshwater supplies continue to decline.

- Have the ability to communicate with a wide range of instruments and equipment that provide required data for irrigation scheduling or rely on generated prescriptions.

- Be a service provided to producers, supported by local, state, and/or federal agencies.

In a more recent publication, Lamm and Rogers (2015) argued against the prevailing perception that scientific irrigation scheduling does not provide benefits when irrigation capacities are severely reduced. They showed that the savings in applied water could still be appreciable under mar- ginal capacities depending on the initial soil water content and the irrigation system's application efficiency.

This review summarizes advances made in developing and implementing scientific irrigation scheduling in the U.S. over the last ten years (since the 2010 Decennial Irrigation Symposium). In addition, some of the challenges and opportunities for future research activities in this field are discussed. Due to their large number, it is not possible to mention every study conducted on irrigation scheduling during the past decade. This article presents key examples that offer general ideas of the direction of advances and recommendations for advancing irrigation scheduling. In addition, the current status of adoption among agricultural producers is discussed based on the information collected by national surveys and large-scale extension/education programs.

\section{STATE OF IRRIGATION SCHEDULING}

Irrigation surveys conducted every five years by the USDA National Agricultural Statistics Service (USDANASS) provide an overview of the state of irrigation scheduling across the U.S. Two surveys have been conducted in the past ten years: the 2013 Farm and Ranch Irrigation Survey and the 2018 Irrigation and Water Management Survey (USDA, 2014, 2019). According to these surveys, qualitative measures have remained the most common methods of deciding when to irrigate, with "condition of crop" being reported for $76 \%$ and "feel of soil" for $38 \%$ of irrigated farms within the top 20 states that collectively account for $90 \%$ of all irrigated area across the U.S. (fig. 1). The next most widely used methods were "personal calendar schedule" and "scheduled by water delivery organization," which were mentioned by $21 \%$ and $19 \%$, respectively, of all irrigated farms in 2018. Irrigation scheduling based on "soil water sensing" was mentioned by only $13 \%$ of irrigated farms in 2018, ranking fifth among the ten methods included in the USDA-NASS surveys. The next methods on the list were "commercial or government scheduling service" and "reports on daily crop evapotranspiration." Scheduling based on "plant water sensing" and "computer simulation models" were the least commonly used methods, ranking lower than "when neighbors begin to irrigate." Comparing the adoption of scientific irrigation scheduling methods among the two survey years (2013 and 2018) shows small differences. The largest difference was observed for soil water sensing methods, which increased from $10 \%$ to $13 \%$ during the five-year period. The use of "plant water sensing" increased from $2 \%$ to $3 \%$, while the adoption of "commercial or government scheduling services," "reports of daily crop evapotranspiration," and "computer simulation models" remained unchanged. Hence, it is evident that further effort is required to promote the adoption of technology for irrigation scheduling.

Notable differences in irrigation scheduling strategies exist among the top 20 irrigated states. The largest range of implementation among these states belonged to "scheduled by water delivery organization," which varied from $0 \%$ in Georgia and Louisiana to $48 \%$ in Utah (fig. 2). Adoption of other quantitative methods was highly variable among the 


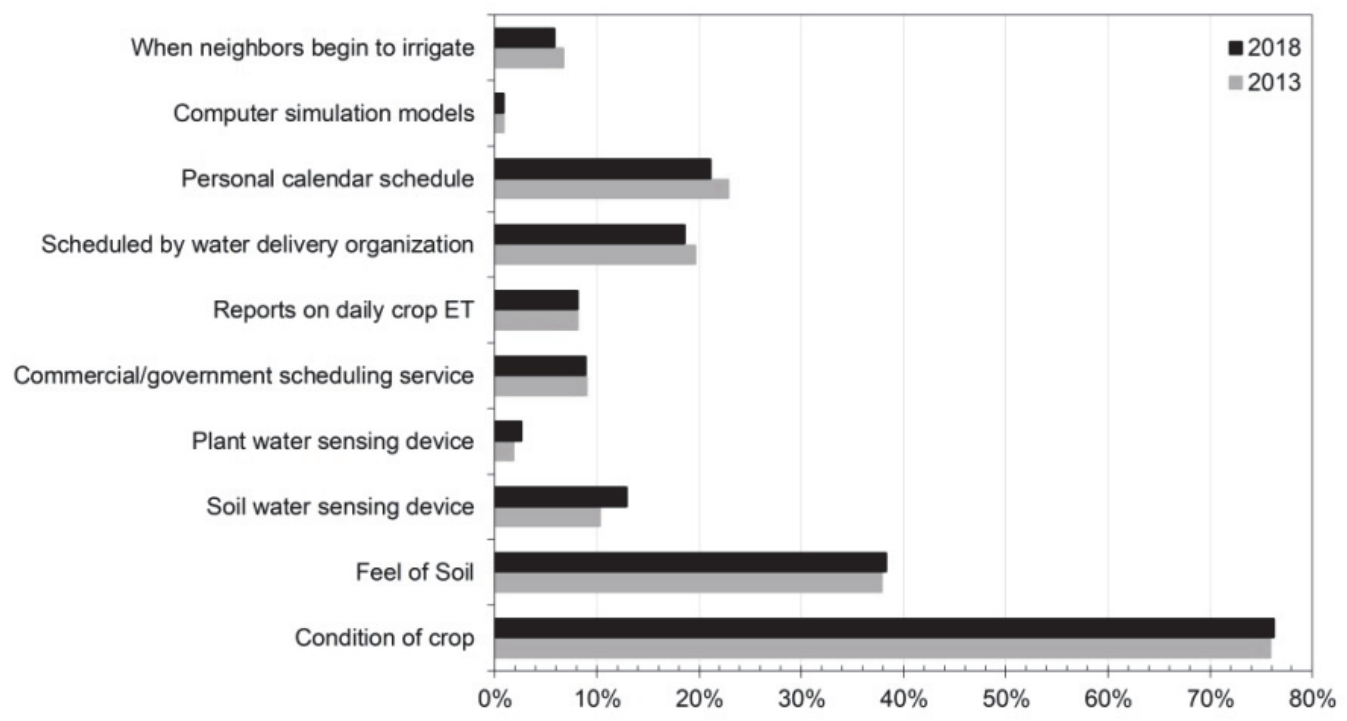

Figure 1. Percentages of irrigated farms within the top 20 irrigated states that reported the use of different methods to decide when to irrigate in surveys conducted in 2013 and 2018. More than one method could be selected, so percentages do not add up to 100.

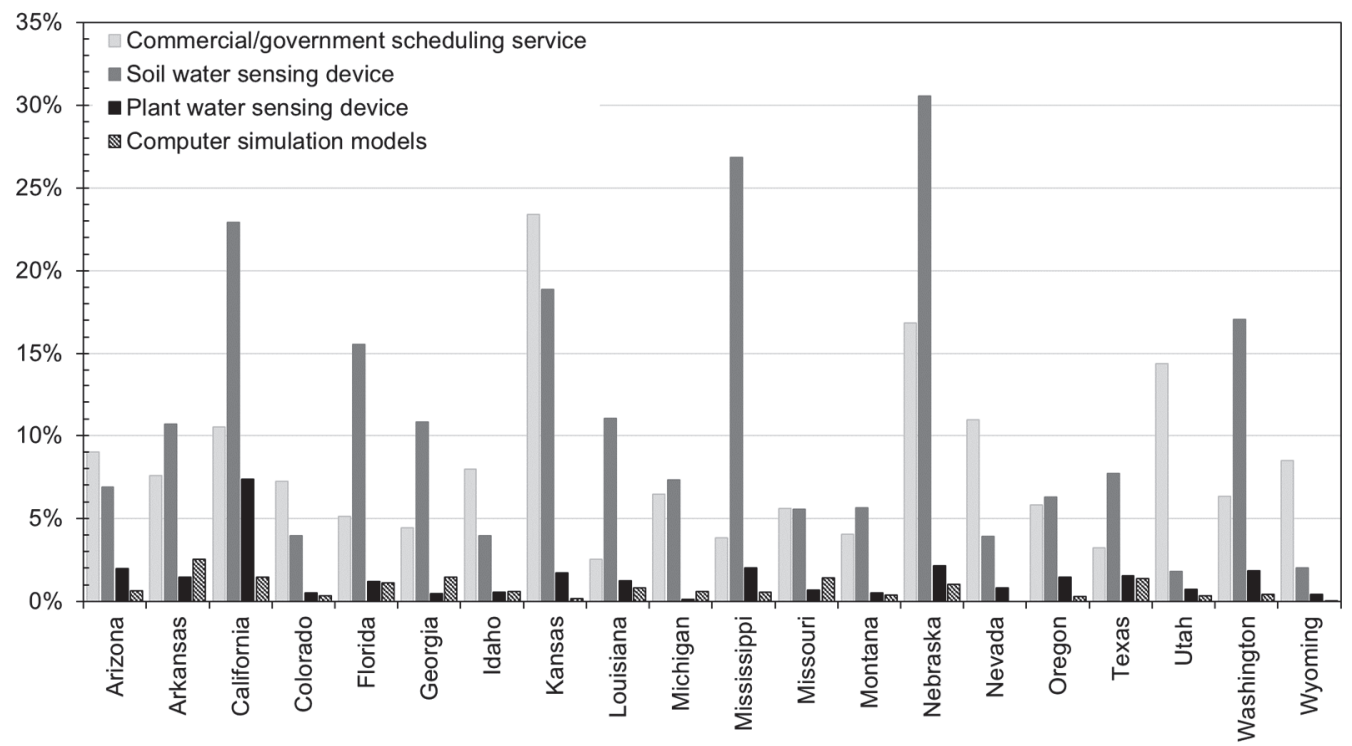

Figure 2. Percentages of irrigated farms in each of the top 20 irrigated states that reported use of four irrigation scheduling methods in 2018.

top 20 states. Use of a "commercial or government scheduling service" was most common in Kansas (23\%), Nebraska $(17 \%)$, and Utah (14\%). The top three adopters of "soil water sensing" were Nebraska (31\%), Mississippi (27\%), and California (23\%). Utah and Wyoming, each with $2 \%$, had the smallest adoption rate of "soil water sensing," which may be due to the dominance of scheduling dictated by water suppliers in these states (i.e., surface water deliveries). A key factor that has played an important role in the success of Nebraska, as the national leader in adopting soil water-based irrigation scheduling, is the Nebraska Agricultural Water Management Network (NAWMN; https://water.unl.edu/category/nawmn). This network is the longest-lasting and largest coordinated irrigation management program in the U.S. and has enabled unprecedented soil water sensing technology adoption and associated large-scale impacts on irrigated agriculture. The NAWMN currently has over 1,600 active partners (producers, crop consultants, state water agencies, and irrigation districts), impacting over 1.3 million ha of irrigated land and reducing irrigation water withdrawal by $55 \mathrm{~mm}$ annually (Irmak et al., 2010).

\section{SCHEDULING BASED ON SOIL WATER STATUS}

As the medium in which water is stored for the crops to use, soil provides a critical interplay between plant and water. Irrigation scheduling based on soil water status (SWS) requires two main types of information: estimates of current/forecasted SWS and estimates of the upper and lower limits (thresholds) of soil water in the root zone against which the SWS can be compared. The upper limit is determined by the soil's plant available water-holding capacity, generally referred to as field capacity. The lower limit, often referred to as the managed allowable depletion (MAD), can 
be more variable depending on several factors, including crop type, growth stage, climatic conditions, and management goal. In most cases, the goal of SWS-based scheduling is to help the irrigation manager track the amount of water in the root zone and maintain it above the MAD level to prevent water stress and resultant yield loss (Rogers, 2012).

The SWS of the managed root zone of a crop can be monitored using soil water sensors or estimated by calculating the mass or volume balance of water in the soil. Hence, SWS-based scheduling can be divided into two subtypes: SWS monitoring and soil water balance (SWB) modeling. The modeling approach is often described as being similar to a checkbook accounting procedure. Effective precipitation and irrigation are the deposits to the account, while the crop water use, evaporation from the soil surface, surface runoff, and deep percolation below the root zone comprise the withdrawals. However, unlike a checkbook, there is a cap on the account balance. When that cap is reached, additional deposits are lost as nonbeneficial water fluxes. There is also a deposit required (i.e., precipitation and/or irrigation) when the balance is too low to ensure optimal crop growth (Rogers, 2012).

\section{Progress Made in the Past Ten Years Soil Water Balance Modeling}

Jensen et al. (1971) described one of the early versions of the SWB approach using a mathematical computer model for estimating soil water depletion. Before the prevalence of the internet, SWB models were standalone software tools that ran locally on individual computers (e.g., Broner and Lambert, 1989; Cahoon et al., 1990). In the 2010s, the accessibility of cloud computing platforms, online weather station networks, and mobile computer devices (i.e., smartphones, tablets) enabled the use of cloud-based SWB apps. Reference evapotranspiration $\left(\mathrm{ET}_{\mathrm{ref}}\right)$ and precipitation $(\mathrm{P})$ are essential components of the SWB. Therefore, most modern computer models for irrigation scheduling rely on $\mathrm{ET}_{\text {ref }}$ and $\mathrm{P}$ estimates derived from weather station networks. Estimates of crop evapotranspiration $\left(\mathrm{ET}_{\mathrm{c}}\right)$, SWS, and recommended irrigation amounts are typically calculated using approaches described by Allen et al. (1998). Depending on irrigation management objectives (e.g., full versus deficit irrigation), the soil water deficit in the root zone is managed relative to the MAD. User interfaces for SWB-based irrigation schedulers come in the form of web-based apps (e.g., Andales et al., 2014; Chauhan et al., 2013), short message service (SMS), and smartphone apps (e.g., Bartlett et al., 2015; Migliaccio et al., 2016; Peters et al., 2013; Vellidis et al., 2016) that have greatly increased accessibility of irrigation scheduling based on SWB. While several SWB models are available, a few examples developed by researchers and extension specialists at land-grant universities in the U.S. are explained here.

In the early 1990s, K-State Research and Extension introduced an Excel spreadsheet program to facilitate irrigation scheduling. This program evolved into KanSched, which has been shown to be useful under a range of climatic conditions and irrigation capacities. KanSched is a free, user-friendly computer program that can be used to establish an irrigation schedule (www.bae.ksu.edu/mobileirrigationlab). KanSched has several versions to match the needs and platforms of users, including Excel (KanSched1), standalone (KanSched2), web-based (KanSched3), and mobile app (KanSched4, available soon) versions (Rogers 2012).

Online geographic information systems (GIS) have increased the spatial coverage of SWB models for irrigation scheduling. For example, the WISE web-based app developed at Colorado State University (http://wise.colostate.edu/; Andales et al., 2014) can be used to schedule irrigations on individual fields across Colorado with automated access to daily weather data (nearest weather stations selectable from a network of 90+) and SSURGO soil profile data (USDA, 2020). Another example is the web-based application CropManage that is available in California (https://cropmanage.ucanr.edu). This SWB model originated for use in short-season vegetable crops but is expanding into agronomic, forage, and orchard crops. A unique aspect of this scheduler is that it also integrates nitrogen management because crop water and nitrogen uses are interdependent.

A key scheduling feature requested by producers is shortterm ( 2 to 7 days) forecasting, as many users need to make decisions a few days before irrigation is needed. This is mainly due to the need to order water in advance in surfaceirrigated districts or to move the irrigation system when the entire field cannot be irrigated instantaneously. Short-term weather forecasts are now being used to estimate $\mathrm{ET}_{\text {ref, }} \mathrm{P}$, and future soil water depletions. Lorite et al. (2015) found that forecasted $\mathrm{ET}_{\text {ref }}$ had relatively low root mean square error (RMSE) values of 0.65 to $0.76 \mathrm{~mm} \mathrm{~d}^{-1}$ during two seasons across 50 locations in semi-arid southern Spain. They noted that forecasted $\mathrm{P}$ would be less accurate because of its relatively high spatial variability. However, depending on the availability of water for irrigation, especially in waterlimited conditions (due to limited capacity of the water source or regulatory/allocation limits), even these low RMSE values can represent a large error over the course of a crop season. Thus, utilization of these kinds of short-term or long-term forecasting approaches is extremely low, especially in water-limited regions.

\section{Soil Water Status Monitoring}

Various types of soil water sensing devices have been developed and are commercially available for monitoring SWS and scheduling irrigation events; these devices include neutron probes, tensiometers, soil resistivity sensors (porous blocks), heat pulse sensors, fiber optic sensors, and electromagnetic (EM) sensors based on capacitance, time domain reflectometry, and frequency domain reflectometry (Susha Lekshmi et al., 2014). Most SWS devices can be divided into two categories based on the type of output (sensor reading) they provide. Electromagnetic (EM) sensors provide estimates of the volumetric soil water content (SWC). Tensiometers and electrical resistance sensors (gypsum blocks and granular matrix sensors) monitor soil matric potential or soil water tension (SWT). SWT can be used in irrigation scheduling when appropriate upper and lower limits in the same tension units are available or when the tension readings are converted to equivalent volumetric SWC estimates using site-specific SWC-SWT relationships (soil-water retention curves). Many research projects in the past ten years have 
focused on evaluating the performance of EM sensors for determining volumetric SWC. Results of these studies indicate that each sensor has advantages and shortcomings in terms of accuracy, reliability, inter-replicate variability, sensitivity to soil salinity, required maintenance, and cost (Varble and Chávez, 2011; Vaz et al., 2013; Rudnick et al., 2015; Sui and Baggard, 2015; Schwartz et al., 2016; Sui, 2017; Datta et al., 2018; Singh et al., 2018; Sui et al., 2019; Zhu et al., 2019; Feng and Sui, 2020; Lo et al., 2020).

Other studies have gone beyond accuracy assessments and have explored implementation of EM sensors in practical irrigation scheduling. For example, Miller et al (2014) evaluated the performance of an automated drip irrigation system that irrigated watermelons based on the readings of multi-sensor capacitance probes. They found that the automation capability offered by the capacitance probes was beneficial in managing irrigation and minimizing leaching in the sandy soils of the coastal study area. Unlike many previous studies, they reported that the factory calibration was as good as site-specific calibration of the capacitance probes in irrigation scheduling. A different type of capacitance sensor was used by Ganjegunte and Clark (2017) in scheduling pecan irrigation in western Texas and achieved considerable reductions in irrigation amounts without negatively impacting the yield when compared to traditional scheduling strategies implemented by local producers. In general, previous research has indicated that irrigation scheduling using EM sensors would result in water saving without negatively affecting yield, but individual and soil-specific sensor calibration for accurate SWC measurement is required under most conditions (Sui et al., 2019; Feng and Sui, 2020; Zotarelli et al., 2011).

Several recent studies have focused on SWT sensors, as they are usually less expensive than EM sensors. Using tensiometers in scheduling irrigation of papaya in south Florida, Migliaccio et al. (2010) observed appreciable reductions in water application and increases in crop production water use efficiency (WUE) compared to traditional set schedules. Irmak et al. (2012) compared SWT-based irrigation scheduling with producer-managed scheduling at 16 Nebraska location-years under center pivot-irrigated maize, representing over 600 ha of irrigated land area. Compared with the producer-managed fields, the use of SWT sensors resulted in $33 \%$ less irrigation water application, about $40 \mathrm{~mm}$ less seasonal $\mathrm{ET}_{\mathrm{c}}, 34 \%$ higher irrigation WUE, no significant differences in crop yield, and $\$ 32.00$ to $\$ 74.10 \mathrm{ha}^{-1}$ in energy savings and additional net return to the farm income. Vellidis et al. (2013) developed a wireless array of SWT sensors integrated with an irrigation scheduling decision support system that was tested for implementing variable-rate irrigation. Liang et al. (2016) developed a web-based tool for converting SWT readings of the same system to volumetric SWC and validated the performance of this approach in scheduling irrigation events for six fields in southern Georgia. In Mississippi, Leininger et al. (2019) reported improvements in yield, net economic return, and irrigation WUE of furrowirrigated peanut when SWT-based thresholds were used in irrigation scheduling.

A promising aspect of SWS monitoring that has received more attention in the past ten years is the development and modification of the internet of things (IoT) and agricultural IoT (Ag IoT), which provide opportunities for faster data gathering, analyses, interpretation, and implementation of results and recommendations for decision-making. Numerous examples exist of $\mathrm{Ag}$ IoT applications for irrigation management. Gutiérrez et al. (2013) developed a wireless sensor network to optimize crop water use. The distributed wireless network of soil water and temperature sensors was installed in the plant root zone, and a gateway unit handled sensor information, triggered actuators, and transmitted data to a web application. The researchers developed an algorithm with threshold values for temperature and SWC that was programmed into the microcontroller-based gateway to control water quantity. The system was powered by photovoltaic panels and had a duplex communication link based on a cellular-internet interface that allowed data inspection and irrigation scheduling to be programmed through a web portal. Dong et al. (2013) developed a proof-of-concept for a wireless underground sensor-aided center pivot (WUSA$\mathrm{CP})$ system that provides autonomous irrigation management by monitoring SWC in real-time. The concept has been tested through long-term field research conducted at the University of Nebraska-Lincoln. The experiment results show that the concept of WUSA-CP is feasible. Through the design of an underground antenna, communication ranges can be improved by up to $400 \%$ compared to conventional antenna designs. Other technical and operational aspects of advanced data acquisition, analysis, and transmission for wireless sensor network applications for automated precision irrigation have been investigated and presented in the past ten years, such as the review of sensing technology and communication mechanisms for the internet of underground things (IOUT) presented by Vuran et al. (2018).

\section{Current Challenges Soil Water Balance Modeling}

A main challenge with SWB modeling is the availability of accurate and representative $\mathrm{ET}_{\text {ref }}$ and $\mathrm{P}$ data. In many cases across the western U.S., there is a shortage of wellmaintained agricultural weather stations. Even if a weather station is available in an irrigated area, its $P$ measurements may not be representative of what was received at the field of interest due to the spatial variability of precipitation. Providing accurate short-term forecasts of irrigation depth and timing requirements is another challenge of SWB modeling and other scheduling strategies. The ability to provide irrigation forecasts relies on the availability and accuracy of short-term crop water use and precipitation forecasts. Jones et al. (2019a) reviewed performance metrics that could be used in assessing quantitative precipitation forecasts and their use in irrigation scheduling. They showed that precipitation forecasts can be useful in early spring, but that there was a decrease in predictive skill during the summer convective precipitation months (Jones et al., 2019b).

\section{Soil Water Status Monitoring}

A major challenge in irrigation scheduling based on SWS monitoring is the need for several monitoring locations within each irrigated field to capture soil heterogeneities. Wireless sensor networks have been developed to address 
this need, such as the system developed by Vellidis et al. (2013). Commercial systems are now available, including Irrometer's IRROmesh, Dynamax SapIP, and other wireless network systems. Yang et al. (2017) developed a reliabilitydriven soil water sensing methodology that applied a genetic algorithm-based optimization technique and a fault detection technique intended to balance cost constraints with system reliability. Other researchers, including Tooker et al. (2012) and Sun et al. (2017), have integrated automated data collected through wireless SWS sensor networks into advanced irrigation control systems to automate irrigation applications according to real-time and near real-time soil water conditions.

Limitations of cost and spatial coverage require that SWS sensors be placed at strategic locations that represent the spatial variability of SWS within a field. Soulis and Elmaloglou (2018) investigated the existence of time-stable representative positions (TSRP) using a two-dimensional numerical model of soil water movement in layered soil with surface drip irrigation. In terms of vertical placement, they found that a TSRP could not be found when a single sensor was used to monitor SWC of the root zone profile, but they were able to identify the best TSRPs when two sensors were used in the profile. Approaches and tools such as this will need to be simplified and operationalized to help irrigation managers and producers strategically place SWS sensors in their fields.

Kukal et al. (2020) argued that the research community has focused mostly on accuracy assessment of SWS sensors and has not paid enough attention to their operational feasibility for variable applications. They developed a framework for SWS sensor selection that takes into consideration factors such as sensor ease of use, cost, and real-time data access, in addition to sensor accuracy. They applied this framework to nine commercial sensors in different installation orientations in fine-textured and coarse-textured soils.

\section{SCheduling BaSEd ON Plant CHARACTERISTICS}

Plant-based methods for irrigation scheduling include thermal sensing, sap flow, leaf or stem water potential, stomatal conductance, and trunk or branch diameter changes. Except for thermal sensing, these methods provide direct measurements of a plant's response to changes in water status. However, to be useful to the user, the information must be normalized, thresholds must be established to recommend irrigation timing, and application depths must be determined, typically using an alternative complementary method.

\section{Progress Made in the Past Ten Years}

Sixteen years ago, in a comprehensive report on plantbased methods for irrigation scheduling, Jones (2004) reported that most applications for automated plant-based sensing were in the developmental stage. However, in the past ten years, automated data collection and storage in conjunction with the availability of off-the-shelf wireless telemetry systems (WTS) have increased the use of plant-based methods. Today's WTS typically come with ready-to-deploy transmitters and receivers. Sensors and modems can be mod- ified with network transceivers so that digitized data can be easily and continuously collected. WTS enable data collection from larger areas within a field, while continuous data collection enables spatiotemporal monitoring of crop water status. WTS conveniently replace wired systems and reduce installation and maintenance costs. A second reason for improving the availability of automated plant-based sensors is the convenience factor. Producers are willing to invest in sensor network systems that provide usable information in a timely manner. Advances in data storage on cloud platforms have increased data accessibility and storage capacity. The cloud can also serve as a computing platform, making software and host hardware less expensive. A third reason for the advancement of automated plant sensing is the interest in site-specific variable-rate irrigation (VRI). VRI systems are available to producers and are mechanically mature. However, sensor feedback is needed to detect spatial variability. Geospatial platforms provide a visual interface for decision support and are becoming more common for irrigation scheduling and control.

Plant-based scheduling approaches can be generally divided into two types according to the method used for collecting data on plant characteristics: direct sensing and remote sensing.

\section{Direct Sensing}

Direct measurement of plant characteristics, such as sap flow, trunk diameter variation, and leaf or stem water potential, has been mostly implemented for irrigation scheduling of nut and fruit trees and wine grapes. Fernández (2017) reviewed the plant-based methods used in irrigation scheduling of woody crops and argued that evaluating the appropriateness of plant-based water stress indicators should be based on the indicator's crop-to-crop variability, sensitivity, earliness in response to water stress, reliability, and robustness under variable environmental conditions. In California, producer surveys conducted by the Center for Environmental Policy and Behavior at University of California, Davis, indicated that adoption of plant-based irrigation scheduling tools is occurring principally in deep-rooted perennial tree nut and fruit crops and more so in the higher and later rainfall areas (300 to $500 \mathrm{~mm}$ rainfall from November through May) of the Sacramento Valley (Brown et al., 2018). Plant-based scheduling has also assisted with successfully developing and implementing irrigation schemes for inducing mild to moderate water stress to reduce applied irrigation water and to control the quality of the fruit. Stewart et al. (2011) reported that regulated deficit irrigation of almond trees resulted in an annual water savings of $127 \mathrm{~mm}$ with no significant reduction in yield, and with only a slight decrease in kernel weight.

Many researchers have found measuring midday stem water potential (SWP) with a pressure chamber to be an effective management tool to aid irrigation scheduling decisions in deep-rooted perennial tree crops such as almonds, walnuts, and prunes in California (Fulton et al., 2014). This method has proven particularly helpful for walnut orchards to make the transition from relying on stored winter and spring rainfall to routine irrigation (Shackel et al., 2018a). In walnut orchards, research has shown that a delay of 60 to 75 days after leafout 
resulted in less tree water stress at harvest. Furthermore, up to $30 \%$ or potentially more water and energy savings have been realized while producing walnuts of higher edible kernel yield and value. By postponing the start of irrigation, it is hypothesized that the soil-water environment is less conducive to fungal diseases like Phytophthora spp., and the trees develop more hardiness that is expressed later in the harvest season. Field observations suggest that similar benefits may be attained with almonds and other perennial tree nut and fruit crops. This is an aspect of plant-based irrigation scheduling methods in need of further research.

In recent years, adoption of the pressure chamber and midday SWP has reached a tipping point among many California producers and consultants, as the potential benefits outweigh labor and other constraints on adoption, and this has generated tremendous interest in automated SWP sensors. An automated sensor that remotely delivers high-frequency SWP measurements is widely desired by producers, and progress is being made with sensor development in the public sector (Shackel et al., 2018b). There is also evidence of an expanding support industry for this irrigation scheduling method (https://pressurebombexpress.com/). However, adoption of this strategy lags that of other irrigation scheduling approaches (fig. 2).

\section{Ground-Based Remote Sensing}

Plant thermal measurements are a valid approach to determining the timing of water applications based on plant response to water status (Evett et al., 2020). Irrigation scheduling methods using plant feedback, in which the feedback incorporates canopy temperature, are typically based on thermal stress indices. Various stress indices have been developed to characterize the level of water stress, including the stress day index (Hiler and Clark, 1971; Hiler et al., 1974), the degrees above non-stressed plants (DANS) (Taghvaeian et al., 2014; DeJonge et al., 2015), the empirical crop water stress index (CWSI) (Idso et al., 1981), the theoretical CWSI (Jackson et al., 1981), the integrated CWSI (iCWSI, O'Shaughnessy et al., 2017), and the time-temperature threshold (TTT) method (Wanjura et al., 1992, 1995; O'Shaughnessy et al., 2012), otherwise known as the biologically identified optimal temperature interactive console (BIOTIC) (Upchurch et al., 1996). Although not all these methods have been used to actively schedule irrigations, thresholds based on regional thermal stress index values from wellwatered and deficit-irrigated crops can generally be used to aid producers with irrigation timing.

An example of a developed plant temperature-based irrigation scheduling system is the irrigation scheduling supervisory control and data acquisition system (ISSCADA) that was patented by the USDA-ARS (Evett et al., 2014) and licensed by Valmont Industries, Inc. The system is comprised of an embedded computer that collects and manages data streams from wireless sensor networks of infrared thermometers as well as weather and soil water sensing data. The ISSCADA system uses a graphical user interface to build dynamic prescription maps. Irrigation scheduling, timing, and amount of water to apply are based on a three-tier approach: maximum, medium, and minimum. The depth of water prescribed to each management zone (MZ) depends on the level of crop stress; an MZ exhibiting high stress will receive the maximum application depth, while an $\mathrm{MZ}$ that is mildly stressed will receive the minimum depth. The prescription maps serve as GIS-based decision support for irrigation scheduling by indicating where, when, and how much water to apply to each area or $\mathrm{MZ}$ of the field (Andrade et al., 2020). A producer can examine the map, accept it or make changes, and then upload it to the control panel. The ISSCADA system can be used with conventional centerpivot sprinklers as well as zone-control VRI sprinklers. Early versions of the ISSCADA system produced maximum cotton lint and corn grain yields that were similar to the yields produced with manual-control irrigation scheduling using weekly neutron probe readings (O'Shaughnessy et al., 2015, 2017). In a two-year beta test, Vories et al. (2019) indicated that the plant-based ISSCADA system resulted in cotton yields similar to the yields produced using the Arkansas Irrigation Scheduling method, but the irrigation water productivity was significantly greater for the ISSCADA system. While the core algorithm for irrigation scheduling in the ISSCADA system is based on the iCWSI, soil water sensing has been added for irrigation scheduling in humid and subhumid climates to prevent over-irrigation, where high relative humidity can confound irrigation signals. Stone et al. (2019) and Sui et al. (2020) showed successful irrigation management of corn and soybean, respectively, using the ISSCADA-hybrid system that combines soil water sensing with plant feedback.

In addition to ground-based remote sensing of plant temperature, active monitoring of vegetation indices using spectral radiometers has been used in irrigation scheduling, especially in providing a measure of crop coefficients in response to actual environmental conditions (Hunsaker et al., 2005). However, remote sensing of vegetation indices has been used in combination with other irrigation scheduling strategies (e.g., SWB modeling) and not as an independent scheduling method. Stone et al. (2016) used the normalized difference vegetative index (NDVI) combined with an SWB model to schedule irrigations for corn using a zone-control VRI center-pivot sprinkler. Soils in the field were highly variable. The NDVI measurements were made with an active spectral radiometric instrument mounted on a tractor with a GPS receiver, and the tractor was periodically driven across the field during the growing season. Corn grain yields and WUE levels were similar to results from other scheduling methods (including SWS monitoring). Novel algorithms that grade the severity of plant disease detected by spectral reflectance sensors could result in new paradigms for site-specific irrigation scheduling, such as deficit irrigation scheduling over mildly infected crops or withholding irrigations over severely infected crops to improve crop water productivity at the field-scale level (Workneh et al., 2017). Handheld spectral radiometers are widely available and could be mounted on a moving platform to increase the area of detection, and miniaturized economical computer vision systems will soon be available on the market (Casanova et al., 2014; Osroosh et al., 2018). 


\section{CurRent Challenges}

Plant-based methods for irrigation scheduling are not as popular among U.S. producers, except in specific crops and irrigation regions of the U.S., and their adoption generally lags all other methods apart from computer simulation (fig. 2). However, the advantages of plant-based methods over soil water status are that they integrate the soil-water environment with the surrounding weather and provide a direct, quantitative indicator of crop water status. Hence, large water and energy savings can be achieved when plant-based indicators are part of the irrigation scheduling toolset. They are also generally less invasive. In addition, ground-based remote sensing approaches can monitor larger areas, ranging from entire trees to entire fields when they are mounted on moving platforms such as tractors or sprinkler irrigation systems. A challenge is to convert the plant feedback information into recommendations that producers understand and trust. This can be accomplished when the approach is introduced into appropriate cropping systems and is given research priority (Fulton et al., 2014). Another challenge is that while plant-based methods can be effective for irrigation timing, their use in determining the actual amount of water that needs to be applied is not as straightforward (Irmak et al., 2000). Thus, these methods need to be supported by other irrigation scheduling methods. Further research on the automation of plant-based scheduling technologies, especially when coupled with telemetry systems, can enhance their utility in irrigated agriculture.

\section{SCHEDULING BASED ON Crop Modeling}

Crop simulation models attempt to integrate several key elements of the farming system, including soil, weather, crop genetics and management practices. With regard to irrigation scheduling they can be used to predict effects of scheduling strategies on crop yield during the season. Crop models range from simple statistical models to mechanistic, processes-based models that can be integrated with machine learning and/or artificial intelligence. Hence, they vary in degree of inputs required, accuracy, and level of technical training and support needed for proficient application.

\section{Progress Made in the Past Ten Years}

Several cropping system models have been successfully used in the U.S. and other countries to evaluate irrigation scheduling strategies, including DSSAT-CSM (Jones et al., 2003), CropSyst (Marsal and Stöckle, 2012), SWAT (Chen et al., 2018), APSIM (Keating et al., 2003), RZWQM (Ma et al., 2012), and AquaCrop (Raes et al., 2012). These models vary in their complexity and in the way that they simulate cropping systems. The crop growth modules within these models can be carbon, radiation, or water driven. Carbondriven models simulate crop growth based on carbon assimilation by leaves through photosynthesis (e.g., CROPGRO models). Radiation-driven models simulate biomass as a function of radiation use efficiency (e.g., CERES models). Water-driven models simulate biomass growth or yield as linearly proportional to transpiration or $\mathrm{ET}_{\mathrm{c}}$ through a water productivity parameter (e.g., AquaCrop).

Most of the reported research on the use of crop simulation models for implementing tactical irrigation scheduling and strategic crop water allocation over the past ten years has focused on retrospective evaluation of irrigation scheduling options based on experimental data and long-term weather data (DeJonge et al., 2011; Ma et al., 2012; Mauget et al., 2013; Saseendran et al., 2015; Kisekka et al., 2016, 2017a; Adhikari et al., 2017; Wibowo et al., 2017; Araya et al., 2018; Foster and Brozović, 2018; Sharda et al., 2019; Masasi et al., 2019b, 2020). With reference to the advances made, most of the progress over the last ten years has focused on improving modeling of the soil water balance, ETc, and irrigation scheduling, as well as data assimilation, coupling crop models to optimization algorithms (e.g., Nguyen et al., 2017), and development of crop-model based decision support systems.

Shelia et al. (2018) coupled the Hydrus 1D model to the DSSAT-CSM to better predict soil water dynamics using the Richards equation. Prior to this work, the soil water balance in DSSAT was simulated using the tipping-bucket approach, which is limited in terms of its ability to fully characterize the unsaturated zone. For example, simulating the effects of a shallow water table on root zone soil water dynamics is not possible with the tipping-bucket approach. Coupling DSSAT with Hydrus also improved the robustness of the model to predict crop response to water stress. Other crop models that provide an option to simulate irrigation management using either the Richards equation or tipping-bucket approach include RZWQM2 and APSIM.

The ability of crop models to be successfully used for irrigation scheduling also depends on how well they simulate ETc. DeJonge and Thorp (2017) improved the modules for simulating ETc in DSSAT to align them with the FAO-56 and ASCE standardized ET approaches commonly used in irrigation scheduling. They added the ASCE standardized ETref equation for both grass and alfalfa as well as the FAO-56 dual crop coefficient approach to determine potential ETc, which included a coefficient for potential evaporation and a basal crop coefficient for potential transpiration. This improved DSSAT's ability to simulate yield and effects of irrigation management on soil water evaporation more realistically.

Considerable progress has also been made in improving how irrigation is modeled within crop models. For example, earlier crop models included simple rules for triggering irrigation, such as a single soil water threshold with unlimited water supply, which is unrealistic for many practical irrigation scheduling situations. Lopez et al. (2017) developed new algorithms for simulating stage-based irrigation scheduling that allowed specifying different soil water thresholds for triggering irrigation at different growth stages in DSSAT. Kisekka et al. (2017b) further improved these algorithms by implementing a limit to irrigation frequency at a given growth stage to mimic hydrologic constraints on water supply that impact irrigation capacity. Ma et al. (2012) improved RZWQM2 by adding moving average constraints on water supply over a five-year period to mimic regulatory constraints on the amount of water an irrigator is allowed to use. Chen et al. (2018) improved the automatic irrigation 
scheduling algorithms in SWAT and tested the improvements against lysimeter data.

Under limited water supplies, irrigation scheduling becomes an optimization problem. There have been some advances in coupling crop models to optimization algorithms in order to identify irrigation schedules that optimize profit, water productivity, or yield (Linker and Kisekka, 2017). Thorp et al. (2010) applied data assimilation of remotely sensed leaf area index to improve the ability of the CSM-CROPSIMCERES-Wheat model to predict yield and ETc. Much work is still needed in this area as model data from various sensors and remote sensing imagery become available.

Some researchers have focused on developing crop model-based decision support tools to enhance the adoption of crop models for irrigation scheduling. Mauget et al. (2013) developed a web-based decision support tool that uses the DSSAT model and historical weather data to generate yield outcomes based on a range of water levels from full to deficit irrigation in the Texas High Plains. Kim and Kisekka (2020) developed a web-based geospatial modeldriven decision support tool called the Food, Agriculture, and Resource Management System (FARMs; http://kisekka.ucdavis.edu/research/crop-modeling-uncertainty-optimization-and-data-driven-decision-support-systems/). FARMs is currently linked to the USDA-NRCS SSURGO soil database and automatically retrieves soil profile information for any field. FARMs is also linked to gridded weather data from NASA POWER and automatically prepares weather data input files. Currently, FARMs only runs the DSSAT crop simulation engine. To enhance crop model use in irrigation scheduling, more work is needed in developing robust, user-friendly web or mobile apps powered through cloud computing.

\section{Current Challenges}

Crop modeling as a decision support tool for crop input management (including irrigation management) has been available and advocated for decades, but practical application of these models, such as GOSSYM/COMAX (Yaron and Bresler, 1983; Boone and Porter, 1997) and COTMAN (Oosterhuis and Bourland, 2008; Vories et al., 2011) has been limited in part by the amount of data and time required to run the models, the costs of hardware and software, and the lack of technical support for end-users. Newer models (available from public and private sector developers) take advantage of automated data acquisition, internet-based software and mobile platforms (apps), integration of data, imbedded models from research, and user-friendly dashboards for data presentation that offer relative convenience for endusers. Many promising models languish due to lack of longterm funding to maintain or update them and to provide ongoing technical support (Boone and Porter, 1997). Many more popular and long-lived models are often misapplied by users who fail to understand the cropping systems for which the models are used or lack the experience and technical background to use the models proficiently. Hence, advancement in the adoption of crop models for irrigation scheduling may require additional intervention and interpretation by qualified experts, who are in short supply.

\section{SCHEDULING BY DEFAULT}

Producers often irrigate because water is available, and they often withhold irrigation to accommodate crop production or harvest operations. This can result in both over-irrigation and under-irrigation. Following are some examples of this type of irrigation scheduling.

\section{Irrigating when Water is Available}

In this situation, water is delivered on a rotational basis. The crop is either irrigated or not irrigated at each irrigation turn. Not irrigating means that it will be a week or more before the opportunity to irrigate presents itself again, which may stress the crop and result in yield reduction. Irrigating at each turn may apply more water than is needed to fill the root zone; this may be more prevalent in surface-irrigated fields. In some cases, the water supply is limited, and an irrigator cannot irrigate all the fields during an irrigation turn. In this case, a decision is made to determine which field has the most critical (most economically justified) need. Produce crops would generally be irrigated before small grains or forage crops.

\section{Scheduling to Accommodate Cropping Practices}

This type of scheduling is common for alfalfa, which is a major crop in arid regions of the U.S. Alfalfa is a good crop when the water supply is uncertain because it can produce a crop with little water and will go dormant without irrigation or precipitation. Alfalfa is generally harvested about every four weeks. During the four-week cutting schedule, generally only about three weeks are available for irrigation. Several days are often necessary for the field to dry-down to accommodate the traffic of cutting, windrowing, baling, and hauling. These operations, along with time for the alfalfa to dry, can take four or five days. Each irrigation system offers unique challenges. Center pivot application rates may be limited, and some center pivots operating $75 \%$ or less of the time cannot provide enough water for alfalfa. Wheel lines (side rolls) may take ten days to complete an irrigation. Hence, some parts of the field will need to wait an extended period to be irrigated after harvest. Surface irrigation can also present a challenge due to the irrigation depth applied at each irrigation. Irrigators in some regions make the decision to irrigate once or twice between cuttings. In heavy soils with higher water tables (1.0 to $1.5 \mathrm{~m}$ below the surface), some irrigators choose to irrigate only once so their fields can be dry enough for harvesting. However, irrigating once each month may result in some crop stress and yield loss. Cropping practices can also influence irrigation scheduling in other crops. At times, it may be necessary to dry-down the soil for cultivation and pesticide or fertilizer application. These delays in irrigation can also result in crop stress.

\section{Irrigating Based on System Capacity or Water Supply}

Some irrigation systems do not have the capacity to keep up with irrigation requirements during the hot and dry summer months. In these cases, an irrigator does all that can be done to keep the irrigation system in operation at all times to avoid falling below the MAD during the dry summer months. A common practice is to try to fill the soil profile prior to or early 
in the growing season. However, preseason and dormant season irrigation is often an inefficient use of irrigation water (Lamm and Rogers, 1985; Musick and Lamm, 1990). In such circumstances, scientific irrigation scheduling can still help conserve water (Lamm and Rogers, 2015), especially during early and late stages of the growing season.

The available water supply may also limit irrigation, and irrigation applications may not match needs based on crop, climate, and soil conditions. In these situations, managed deficit irrigation may enhance crop water productivity by distributing the limited available water supplies in a manner that protects the crop during more sensitive growth stages.

\section{Irrigating Based on Water Rights}

Some irrigators concerned about "use it or lose it" regulations are unfortunately influenced by a misinterpretation of their water rights and irrigate at their full diversion right regardless of crop water needs. This is a misconception of "forfeiture or abandonment of water rights," beneficial use, and waste of water. While there are differences in state water rights, water rights are not lost by beneficial use of water and good irrigation scheduling practices.

\section{Progress Made in the Past Ten Years}

Progress has been made by several irrigation companies and regions where sprinkler and center pivot irrigation have replaced surface irrigation, especially where water is available to producers on a nearly continuous (on-demand) basis, allowing flexibility in irrigation scheduling. Some large irrigation districts that primarily use surface irrigation, such as the Imperial Irrigation District in California, provide water on a request basis rather than on a rotational basis. In some regions, subsurface drip irrigation (SDI) has been gaining acceptance due to this technology's ability to reduce evaporation losses and farm labor requirements. To accommodate water supply needs, on-farm water facilities have been constructed to provide water between irrigation turns. Changes in farming practices will require adjustments in irrigation management, but having adequate water supplies (off-farm and on-farm) and a well-designed and operated irrigation system can help accommodate farming practices without resulting in crop yield reduction. Replacing canal and lateral systems with piped systems has reduced loses and provided more flexibility due to downstream (turnout) water control. These systems, coupled with on-farm storage reservoirs, have increased ability to transition to on-demand irrigation delivery to accommodate improved irrigation scheduling. Several local and federal organizations (e.g., NRCS and USBR) have provided funding to assist in system conversions to pipelines.

\section{Current Challenges}

When irrigation is based on water turns (rotational), the timing, flowrate, and duration of irrigation events cannot be modified, but there are opportunities to delay the onset of the irrigation season or to terminate irrigations earlier than usual. Masasi et al. (2019a) showed that earlier termination of cotton irrigation could result in considerable water conservation, with variable impacts on cotton yield and fiber quality de- pending on the late-season precipitation. Similarly, wheat irrigation can be terminated before completion of grain fill with no impact on yield and quality (Torrion and Stougaard, 2017). In some areas, adoption of new irrigation systems has introduced new challenges to irrigation management. One example is the Lugert-Altus Irrigation District in southwest Oklahoma, where about a third of the district has switched from furrow irrigation to SDI. While the furrow-irrigated lands receive water on rotational basis, SDI farms demand daily water deliveries, albeit at a fraction of the flowrate of furrow-irrigated fields. The shift to SDI has created challenges in terms of managing water deliveries in the district and minimizing evaporation, seepage, and spill losses in secondary and tertiary canals (Shahdany et al., 2019).

\section{OPPORTUNITIES AND THE PATH FoRWARD}

Based on the review of the progress made in irrigation scheduling in the past ten years and the existing challenges, several opportunities can be identified for improving the accuracy, reliability, and adoption of scientific irrigation scheduling strategies. Some of these opportunities and recommendations are nontechnical, while others are technical and may apply to all scheduling approaches (general) or only one or a few of them (specific).

\section{NONTECHNICAL OPPORTUNITIES \\ Collaborations}

Increased collaboration among different disciplines and stakeholders is strongly encouraged. Irrigation scientists and engineers should collaborate with their counterparts from other disciplines to provide more comprehensive solutions. Management decisions, including irrigation decisions, by agricultural producers are interdependent within cropping systems, as inputs are managed in the context of crop needs (integrated crop management). Future irrigation scheduling methods should attempt to offer adaptive management solutions and provide options to integrate other key decisions, such as nutrient management. Collaborations with a wide range of stakeholders (producer groups, state agencies, and federal organizations) are also important for presenting a unified, less confusing message about scheduling strategies, as well as for developing and securing financial and other incentives for adoption of effective scheduling approaches.

\section{Funding}

Availability of adequate funding from a variety of public and private sources is a key requirement for the continuous development, field evaluation, and demonstration (research and extension) of scientific irrigation scheduling methods, as well as for training the next generation of irrigation scientists and engineers (teaching).

\section{GENERAL TECHNICAL OPPORTUNITIES \\ On-Site Measurements}

Many scheduling strategies, especially those that rely on modeling approaches (SWB and crop modeling), would ben- 
efit from on-site measurements of precipitation (P) and irrigation applications. Most available modeling approaches rely on $\mathrm{P}$ records from nearby weather stations or from gridded estimates. However, these estimates may not represent the amount of $\mathrm{P}$ received at the field of interest, due to the spatial variability of this parameter. On-site P measurement can considerably improve the accuracy of irrigation scheduling. Similarly, accurate estimation of the irrigation application amount is a critical step toward implementing scientific irrigation scheduling. Irrigation water resources lend themselves to the famous observation that "you can't manage what you can't measure." While flow measuring devices have improved considerably in their accuracy, ease of use, and cost in recent years, many irrigators do not measure this key parameter. Promoting measurement of irrigation application can reduce the error of irrigation scheduling approaches, especially those that rely on modeling and userprovided information rather than soil and plant feedback.

\section{Forecasting}

Many producers need to make irrigation decisions several days in advance. These users need scheduling methods that are capable of accurately forecasting short-term crop water use. Of equal importance is short-term forecasts of precipitation to allow delay of irrigation and capture of the precipitation. Improvements in the accuracy of weather forecasts will depend on improvements in predictive numerical weather models and downscaling techniques developed by atmospheric scientists. However, irrigation scientists should evaluate the skill of these forecasts through comparisons with on-site measurements. Forecast skill varies by region. For example, uncertainty in quantitative precipitation forecasts may be high in semi-arid regions because of the localized nature of convective thunderstorms. In these cases, it may be more effective to use historical weather statistics (e.g., mean, variance, historical extremes) to estimate future weather. Forecasted weather can then be replaced or corrected with on-site weather data as the season progresses. In many forecasting models, while the period or timing of the precipitation has improved in the last several years, the accuracy of the amount of forecasted precipitation still needs to be improved, especially at sub-grid scale (NRC, 2002). Short-term weather forecasting at the field scale needs further research to enhance adoption of forecasting models in on-farm irrigation scheduling.

\section{Requirements}

Many scientific irrigation scheduling strategies have appreciable requirements for input data, time, labor, and/or financial investment, which make them less appealing to potential users. Despite major advances in reducing these requirements, improving the adoption of scientific scheduling approaches relies on minimizing their demand on the limited human and financial resources available to agricultural producers.

\section{Decision Support Systems}

Several new products have been developed in the past ten years that transform estimates of soil and plant characteristics into practical and easy-to-understand irrigation deci- sions. However, many other methods still provide less useful, raw or semi-raw estimates that cannot be readily translated into irrigation management decisions by nontechnical users. Future irrigation schedulers should bridge this gap and assist users with decisions related to the selection of input data (in the case of model-based scheduling) and/or the number and location of sensing devices (in the case of sensorbased scheduling). Internet-based and user-friendly mobile device applications offer appreciable improvements in the end-user experience compared to some older systems. Internet-based applications can be more easily updated, often without any action required of the end-user or subscriber and without incompatibilities with computer operating systems. Easy to use, readily accessible, mobile device irrigation apps are likely to be more attractive to the current and future generations of end-users. Examples include a range of smart irrigation apps available from the University of Florida and the University of Georgia (https://smartirrigationapps.org, Migliaccio et al., 2016).

\section{Demonstrating Effectiveness}

Some previous research projects on scientific irrigation scheduling have failed to properly design the experiment or have not documented critical information or certain benefits of implementing scheduling approaches to demonstrate their full potential. It is highly recommended that future research projects follow guidelines for appropriate experimental design and include treatments that show the advantages of scientific irrigation scheduling compared to conventional methods. They should also attempt to document reductions in use of water, energy, and nutrients and conduct economic analysis on the net benefits of implementing irrigation scheduling. The benefits that can be realized at larger scales (district and watershed) also deserve more attention (Lea-Cox, 2012). In addition, well designed and documented research projects should be followed by extension projects at local levels to demonstrate the effectiveness of developed methods in a wide range of soil, crop, and climate conditions. Producers are more likely to adopt practices (including irrigation scheduling) that have been tested and demonstrated in their regions and have shown clear agronomic and financial benefits.

\section{SPECIFIC TECHNICAL OPPORTUNITIES Scheduling Based on Soil Water Status}

While irrigation scientists and engineers have been deploying numerous wireless instrumentations for irrigation management, recent advances in wireless sensor networks and Ag IoT devices make these deployments more userfriendly and enable faster data gathering by transmitting and managing data in the cloud domain, which also makes autonomous irrigation and other agricultural operations and management more feasible. These wireless technologies will continue to be developed and adopted for automated irrigation scheduling in the future.

\section{Scheduling Based on Plant Characteristics}

The path forward with plant-based sensors will likely be driven by aerial imagery using thermal and spectral sensing from manned and unmanned aerial vehicles and satellite 
platforms. The advantages of these technologies are data acquisition without interference with farming operations, and frequent snapshots of an entire field at the same time of day, allowing evaluation of the spatial and temporal heterogeneity of crop water status. Currently, data from these largerscale platforms are being assimilated with crop, soil water balance, and small basin watershed models for irrigation scheduling (Barker et al., 2018, Bhatti et al., 2020) and precision irrigation practices, such as those being tested for viticulture (Sanchez et al., 2017; Lei et al., 2020). Adoption will depend on the accuracy, availability, and usability of the data by end-users.

\section{Scheduling by Default}

Implementing scientific irrigation scheduling may not be feasible under some circumstances, such as when delivery schedules are determined by water suppliers. These situations require different types of scheduling tools that could still achieve irrigation scheduling goals. Examples include optimizing scheduling at the beginning and end of the irrigation season and developing decision support tools to help decide on whether to accept or pass on irrigation turns.

\section{Conclusions}

Adoption of scientific irrigation scheduling approaches, although growing slowly, has remained limited across the U.S. In 2018, the most popular scientific method was scheduling based on soil water sensing, which was reported by $13 \%$ of irrigated farms in the top 20 irrigated states. Despite this overall slow transfer of technology, some states have shown a considerable increase in adoption. For soil water sensing, for example, $23 \%$ to $31 \%$ of the irrigated farms in California, Mississippi, and Nebraska now use this scheduling strategy. These successful cases should be studied to identify possible approaches that can be implemented in other states to improve adoption of scientific irrigation scheduling.

This review of the progress made in irrigation scheduling in the past ten years and discussion of the main challenges and opportunities in conducting future research considered four major strategies, including scheduling based on soil water status, plant characteristics, crop modeling, and scheduling by default. Two nontechnical opportunities were identified when considering the path forward: (1) increased collaboration of irrigation professionals with scientists and engineers in other disciplines and with other stakeholders and (2) increased funding for sustaining research, extension, and teaching efforts in the field of irrigation scheduling. In addition, eight general and specific technical opportunities were discussed in detail. These opportunities included (1) promoting on-site measurement of water applications (precipitation and irrigation), (2) including short-term forecasts in irrigation schedulers, (3) reducing data, time, labor, and cost requirements of schedulers, (4) providing user-friendly decision support systems, (5) demonstrating the effectiveness of scientific irrigation scheduling, (6) advancing wireless sensor networks and IoT applications in irrigation scheduling, (7) incorporating remotely sensed data in scheduling, and (8) developing customized scheduling approaches for situations when scheduling is less flexible due to the constraints imposed by water supplier, cropping practices, system capacity, and/or water rights.

\section{ACKNOWLEDGEMENTS}

This work was partially supported by the USDA-NRCS Conservation Innovation Grants program under award numbers NR203A750008G007 and 69-3A75-17-279. Partial support was also provided by the USDA National Institute of Food and Agriculture (NIFA) under award number 201668007-25066.

\section{REFERENCES}

Adhikari, P., Gowda, P. H., Marek, G. W., Brauer, D. K., Kisekka, I., Northup, B., \& Rocateli, A. (2017). Calibration and validation of CSM-CROPGRO-cotton model using lysimeter data in the Texas High Plains. J. Contemp. Water Res. Educ., 162(1), 6178. https://doi.org/10.1111/j.1936-704X.2017.03260.x

Allen, R. G., Pereira, L. S., Raes, D., \& Smith, M. (1998). Crop evapotranspiration: Guidelines for computing crop water requirements. Irrigation and Drainage Paper No. 56. Rome, Italy: United Nations FAO.

Andales, A. A., Bauder, T. A., \& Arabi, M. (2014). A mobile irrigation water management system using a collaborative GIS and weather station networks. In Practical applications of agricultural system models to optimize the use of limited water (pp. 53-84). Madison, WI: ASA, CSSA, SSSA. https://doi.org/10.2134/advagricsystmodel5.c3

Andrade, M. A., O'Shaughnessy, S. A., \& Evett, S. R. (2020). ARSPivot, a sensor-based decision support software for variable-rate irrigation center pivot systems: Part A. Development. Trans. ASABE, 63(5), https://doi.org/10.13031/trans.13907', in press.

Araya, A., Kisekka, I., Gowda, P. H., \& Prasad, P. V. (2018). Grain sorghum production functions under different irrigation capacities. Agric. Water Mgmt., 203, 261-271. https://doi.org/10.1016/j.agwat.2018.03.010

Barker, J. B., Heeren, D. M., Neale, C. M., \& Rudnick, D. R. (2018). Evaluation of variable-rate irrigation using a remotesensing-based model. Agric. Water Mgmt., 203, 63-74. https://doi.org/10.1016/j.agwat.2018.02.022

Bartlett, A. C., Andales, A. A., Arabi, M., \& Bauder, T. A. (2015). A smartphone app to extend use of a cloud-based irrigation scheduling tool. Comput. Electron. Agric., 111, 127-130. https://doi.org/10.1016/j.compag.2014.12.021

Bhatti, S., Heeren, D. M., Barker, J. B., Neale, C. M., Woldt, W. E., Maguire, M. S., \& Rudnick, D. R. (2020). Site-specific irrigation management in a sub-humid climate using a spatial evapotranspiration model with satellite and airborne imagery. Agric. Water Mgmt., 230, 105950. https://doi.org/10.1016/j.agwat.2019.105950

Boone, K., \& Porter, D. O. (1997). GOSSYM/COMAX: The quixotic quest. Proc. Beltwide Cotton Conf (pp. 380-383). Memphis, TN: National Cotton Council.

Broner, I., \& Lambert, J. (1989). Optimal scheduling of irrigation machines: I. Model development. J. Irrig. Drain. Eng., 115(5), 862-879. https://doi.org/10.1061/(ASCE)07339437(1989)115:5(862)

Brown, P., Lubell, P., Rudnick, J., Darshan, S., \& Tatge, S. (2018). Barriers to adoption of improved nitrogen management practices. Davis, CA: UC Davis Center for Environmental Policy and Behavior. Retrieved from https://environmentalpolicy.ucdavis.edu/sites/g/files/dgvnsk686 
6/files/2019-

02/Grower\%20Surveys\%20Research\%20Brief March\%202018 .pdf

Cahoon, J., Ferguson, J., Edwards, D., \& Tacker, P. (1990). A microcomputer-based irrigation scheduler for the humid midsouth region. Appl. Eng. Agric., 6(3), 289-295. https://doi.org/10.13031/2013.26384

Casanova, J. J., O'Shaughnessy, S. A., Evett, S. R., \& Rush, C. M. (2014). Development of a wireless computer vision instrument to detect biotic stress in wheat. Sensors, 14(9), 17753-17769. https://doi.org/10.3390/s140917753

Chauhan, Y. S., Wright, G. C., Holzworth, D., Rachaputi, R. C., \& Payero, J. O. (2013). AQUAMAN: A web-based decision support system for irrigation scheduling in peanuts. Irrig. Sci., 31(3), 271-283. https://doi.org/10.1007/s00271-011-0296-y

Chen, Y., Marek, G. W., Marek, T. H., Brauer, D. K., \& Srinivasan, R. (2018). Improving SWAT auto-irrigation functions for simulating agricultural irrigation management using long-term lysimeter field data. Environ. Model. Softw., 99, 25-38. https://doi.org/10.1016/j.envsoft.2017.09.013

Datta, S., Taghvaeian, S., Ochsner, T. E., Moriasi, D., Gowda, P., \& Steiner, J. L. (2018). Performance assessment of five different soil moisture sensors under irrigated field conditions in Oklahoma. Sensors, 18(11), 3786. https://doi.org/10.3390/s18113786

DeJonge, K. C., \& Thorp, K. R. (2017). Implementing standardized reference evapotranspiration and dual crop coefficient approach in the DSSAT cropping system model. Trans. ASABE, 60(6), 1965-1981. https://doi.org/10.13031/trans.12321

DeJonge, K. C., Andales, A. A., Ascough II, J. C., \& Hansen, N. C. (2011). Modeling of full and limited irrigation scenarios for corn in a semiarid environment. Trans. ASABE, 54(2), 481-492. https://doi.org/10.13031/2013.36451

DeJonge, K. C., Taghvaeian, S., Trout, T. J., \& Comas, L. H. (2015). Comparison of canopy temperature-based water stress indices for maize. Agric. Water Mgmt., 156, 51-62. https://doi.org/10.1016/j.agwat.2015.03.023

Dong, X., Vuran, M. C., \& Irmak, S. (2013). Autonomous precision agriculture through integration of wireless underground sensor networks with center pivot irrigation systems. Ad Hoc Networks, 11(7), 1975-1987. https://doi.org/10.1016/j.adhoc.2012.06.012

Evett, S. R., O’Shaughnessy, S. A., \& Peters, R. T. (2014). Irrigation scheduling and supervisory control and data acquisition system for moving and static irrigation systems. U.S. Patent No. 8,924,031 B1.

Evett, S. R., O’Shaughnessy, S. A., Andrade, M. A., Colaizzi, P. D., Schwartz, R. C., Schomberg, H. S., ... Sui, R. (2020). Theory and development of a VRI decision support system: The USDAARS ISSCADA approach. Trans. ASABE, 63(5), https://doi.org/10.13031/trans.13922", in press.

Feng, G., \& Sui, R. (2020). Evaluation and calibration of soil moisture sensors in undisturbed soils. Trans. ASABE, 63(2), 265-274. https://doi.org/10.13031/trans.13428

Fernández, J. E. (2017). Plant-based methods for irrigation scheduling of woody crops. Horticulturae, 3(2), 35-. https://doi.org/10.3390/horticulturae3020035

Foster, T., \& Brozović, N. (2018). Simulating crop-water production functions using crop growth models to support water policy assessments. Ecol. Econ., 152, 9-21.

Fulton, A., Grant, J., Buchner, R., \& Connell, J. (2014). Using the pressure chamber for irrigation management in walnut, almond, and prune. UC ANR Publ. 8503. Davis, CA: University of California, Department of Agriculture and Natural Resources. https://doi.org/10.3733/ucanr.8503
Ganjegunte, G., \& Clark, J. (2017). Improved irrigation scheduling for freshwater conservation in the desert southwest U.S. Irrig. Sci., 35(4), 315-326. https://doi.org/10.1007/s00271-017-0546-8

Giannakis, E., Bruggeman, A., Djuma, H., Kozyra, J., \& Hammer, J. (2016). Water pricing and irrigation across Europe:

Opportunities and constraints for adopting irrigation scheduling decision support systems. Water Supply, 16(1), 245-252. https://doi.org/10.2166/ws.2015.136

Gutiérrez, J., Villa-Medina, J. F., Nieto-Garibay, A., \& PortaGándara, M. A. (2013). Automated irrigation system using a wireless sensor network and GPRS module. IEEE Trans. Instrumentation Measurement, 63(1), 166-176. https://doi.org/10.1109/TIM.2013.2276487

Henggeler, J. C., Robinson, P. M., \& Scherer, T. F. (2010). Irrigation scheduling programs of the last ten years. Proc. 5th National Decennial Irrigation Conf. St. Joseph, MI: ASABE. https://doi.org/10.13031/2013.35835

Hiler, E. A., \& Clark, J. (1971). Stress day index to characterize effects of water stress on crop yields. Trans. ASAE, 14(4), 757761. https://doi.org/10.13031/2013.38384

Hiler, E. A., Howell, T. A., Lewis, R. B., \& Boos, R. P. (1974). Irrigation timing by the stress day index method. Trans. ASAE, 17(3), 393-398. https://doi.org/10.13031/2013.36867

Hillyer, C. C., \& Robinson, P. (2010). Envisioning the next generation of irrigation schedulers. Proc. 5th National Decennial Irrigation Conf. St. Joseph, MI: ASABE. https://doi.org/10.13031/2013.35836

Hunsaker, D. J., Barnes, E. M., Clarke, T. R., Fitzgerald, G. J., \& Pinter Jr, P. J. (2005). Cotton irrigation scheduling using remotely sensed and FAO-56 basal crop coefficients. Trans. ASAE, 48(4), 1395-1407. https://doi.org/10.13031/2013.19197

Idso, S. B., Jackson, R. D., Pinter, P. J., Reginato, R. J., \& Hatfield, J. L. (1981). Normalizing the stress-degree-day parameter for environmental variability. Agric. Meteorol., 24, 45-55. https://doi.org/10.1016/0002-1571(81)90032-7

Irmak, S. (2015). Interannual variation in long-term center pivotirrigated maize evapotranspiration and various water productivity response indices: I. Grain yield, actual and basal evapotranspiration, irrigation-yield production functions, evapotranspiration-yield production functions, and yield response factors. J. Irrig. Drain. Eng., 141(5), 04014068. https://doi.org/10.1061/(ASCE)IR.1943-4774.0000825

Irmak, S., Burgert, M. J., Yang, H. S., Cassman, K. G., Walters, D. T., Rathje, W. R., ... Teichmeier, G. J. (2012). Large-scale onfarm implementation of soil moisture-based irrigation management strategies for increasing maize water productivity. Trans. ASABE, 55(3), 881-894. https://doi.org/10.13031/2013.41521

Irmak, S., Haman, D. Z., \& Bastug, R. (2000). Determination of crop water stress index for irrigation timing and yield estimation of corn. Agron. J., 92(6), 1221-1227. https://doi.org/10.2134/agronj2000.9261221x

Irmak, S., Rees, J. M., Zoubek, G. L., van DeWalle, B. S., Rathje, W. R., DeBuhr, R., ... Christiansen, A. P. (2010). Nebraska agricultural water management demonstration network (NAWMDN): Integrating research and extension/outreach. Appl. Eng. Agric., 26(4), 599-613. https://doi.org/10.13031/2013.32066

Jackson, R. D., Idso, S. B., Reginato, R. J., \& Pinter Jr., P. J. (1981). Canopy temperature as a crop water stress indicator. Water Resour. Res., 17(4), 1133-1138. https://doi.org/10.1029/WR017i004p01133

Jensen, M. E., Wright, J. L., \& Pratt, B. J. (1971). Estimating soil moisture depletion from climate, crop, and soil data. Trans. ASAE, 14(5), 954-959. https://doi.org/10.13031/2013.38430 
Jones, A. S., Andales, A. A., Chávez, J. L., McGovern, C., Smith, G. E., David, O., \& Fletcher, S. J. (2019a). Use of predictive weather uncertainties in an irrigation scheduling tool: Part I. A review of metrics and adjoint methods. JAWRA, 56(2), 187-200. https://doi.org/10.1111/1752-1688.12810

Jones, A. S., Andales, A. A., Chávez, J. L., McGovern, C., Smith, G. E., David, O., \& Fletcher, S. J. (2019b). Use of predictive weather uncertainties in an irrigation scheduling tool: Part II. An application of metrics and adjoints. JAWRA, 56(2), 201-211. https://doi.org/10.1111/1752-1688.12806

Jones, H. G. (2004). Irrigation scheduling: Advantages and pitfalls of plant-based methods. J. Exp. Bot., 55(407), 2427-2436. https://doi.org/10.1093/jxb/erh213

Jones, J. W., Hoogenboom, G., Porter, C. H., Boote, K. J., Batchelor, W. D., Hunt, L. A., ... Ritchie, J. T. (2003). The DSSAT cropping system model. European J. Agron., 18(3), 235-265. https://doi.org/10.1016/S1161-0301(02)00107-7

Keating, B. A., Carberry, P. S., Hammer, G. L., Probert, M. E., Robertson, M. J., Holzworth, D., ... Smith, C. J. (2003). An overview of APSIM, a model designed for farming systems simulation. European J. Agron., 18(3), 267-288. https://doi.org/10.1016/S1161-0301(02)00108-9

Kim, S. J., \& Kisekka, I. (2020). FARMs: A geospatial crop modeling and data-driven precision agriculture system for optimizing agricultural and resource management. Comput. Electron. Agric., submitted.

Kisekka, I., Aguilar, J. P., Rogers, D. H., Holman, J., O’Brien, D. M., \& Klocke, N. (2016). Assessing deficit irrigation strategies for corn using simulation. Trans. ASABE, 59(1), 303-317. https://doi.org/10.13031/trans.59.11206

Kisekka, I., Porter, C. H., Shelia, V., \& Hoogenboom, G. (2017b). Improving irrigation scheduling in DSSAT-CSM. Retrieved from http://kisekka.ucdavis.edu/wpcontent/uploads/2018/03/Improving-irrigation-schedulingalgorithms-in-DSSAT.pdf

Kisekka, I., Schlegel, A., Ma, L., Gowda, P. H., \& Prasad, P. V. V. (2017a). Optimizing preplant irrigation for maize under limited water in the high plains. Agric. Water Mgmt., 187, 154-163. https://doi.org/10.1016/j.agwat.2017.03.023

Kukal, M. S., Irmak, S., \& Sharma, K. (2020). Development and application of a performance and operational feasibility guide to facilitate adoption of soil moisture sensors. Sustainability, 12(1), 321. https://doi.org/10.3390/su12010321

Lamm, F. R., \& Rogers, D. H. (1985). Soil water recharge function as a tool for preseason irrigation. Trans. ASAE, 28(5), 15211525. https://doi.org/10.13031/2013.32470

Lamm, F. R., \& Rogers, D. H. (2015). The importance of irrigation scheduling for marginal capacity systems growing corn. Appl. Eng. Agric., 31(2), 261-265. https://doi.org/10.13031/aea.31.10966

Lea-Cox, J. D. (2012). Using wireless sensor networks for precision irrigation scheduling. In Problems, perspectives, and challenges of agricultural water management (pp. 233-258). Rijeka, Croatia: InTech Press.

Lei, F., Crow, W. T., Kustas, W. P., Dong, J., Yang, Y., Knipper, K. R., ... Dokoozlian, N. (2020). Data assimilation of highresolution thermal and radar remote sensing retrievals for soil moisture monitoring in a drip-irrigated vineyard. Remote Sens. Environ., 239, 111622. https://doi.org/10.1016/j.rse.2019.111622

Leininger, S. D., Krutz, L. J., Sarver, J. M., Gore, J., Henn, A., Bryant, C. J., ... Spencer, G. D. (2019). Establishing irrigation thresholds for furrow-irrigated peanuts. Crop Forage Turfgrass Mgmt., 5(1), 180059. https://doi.org/10.2134/cftm2018.08.0059

Liang, X., Liakos, V., Wendroth, O., \& Vellidis, G. (2016). Scheduling irrigation using an approach based on the van
Genuchten model. Agric. Water Mgmt., 176, 170-179. https://doi.org/10.1016/j.agwat.2016.05.030

Lichtenberg, E., Majsztrik, J., \& Saavoss, M. (2015). Grower demand for sensor-controlled irrigation. Water Resour. Res., 51(1), 341-358. https://doi.org/10.1002/2014wr015807

Linker, R., \& Kisekka, I. (2017). Model-based deficit irrigation of maize in Kansas. Trans. ASABE, 60(6), 2011-2022. https://doi.org/10.13031/trans.12341

Lo, T. H., Rudnick, D. R., Singh, J., Nakabuye, H. N., Katimbo, A., Heeren, D. M., \& Ge, Y. (2020). Field assessment of interreplicate variability from eight electromagnetic soil moisture sensors. Agric. Water Mgmt., 231, 105984. https://doi.org/10.1016/j.agwat.2019.105984

Lopez, J. R., Winter, J. M., Elliott, J., Ruane, A. C., Porter, C., \& Hoogenboom, G. (2017). Integrating growth stage deficit irrigation into a process-based crop model. Agric. Forest Meteorol., 243, 84-92. https://doi.org/10.1016/j.agrformet.2017.05.001

Lorite, I. J., Ramírez-Cuesta, J. M., Cruz-Blanco, M., \& Santos, C. (2015). Using weather forecast data for irrigation scheduling under semi-arid conditions. Irrig. Sci., 33(6), 411-427. https://doi.org/10.1007/s00271-015-0478-0

Ma, L., Trout, T. J., Ahuja, L. R., Bausch, W. C., Saseendran, S. A., Malone, R. W., \& Nielsen, D. C. (2012). Calibrating RZWQM2 model for maize responses to deficit irrigation. Agric. Water Mgmt., 103, 140-149.

https://doi.org/10.1016/j.agwat.2011.11.005

Marsal, J., \& Stöckle, C. O. (2012). Use of CropSyst as a decision support system for scheduling regulated deficit irrigation in a pear orchard. Irrig. Sci., 30(2), 139-147. https://doi.org/10.1007/s00271-011-0273-5

Masasi, B., Taghvaeian, S., Boman, R., \& Datta, S. (2019a). Impacts of irrigation termination date on cotton yield and irrigation requirement. Agric., 9(2), 39. https://doi.org/10.3390/agriculture9020039

Masasi, B., Taghvaeian, S., Gowda, P. H., Marek, G., \& Boman, R. (2020). Validation and application of AquaCrop for irrigated cotton in the Southern Great Plains of U.S. Irrig. Sci., 2020. https://doi.org/10.1007/s00271-020-00665-4

Masasi, B., Taghvaeian, S., Gowda, P. H., Warren, J., \& Marek, G. (2019b). Simulating soil water content, evapotranspiration, and yield of variably irrigated grain sorghum using AquaCrop. JAWRA, 55(4), 976-993. https://doi.org/10.1111/17521688.12757

Mauget, S., Leiker, G., \& Nair, S. (2013). A web application for cotton irrigation management on the U.S. Southern High Plains: Part I. Crop yield modeling and profit analysis. Comput. Electron. Agric., 99, 248-257. https://doi.org/10.1016/j.compag.2013.10.003

Migliaccio, K. W., Morgan, K. T., Vellidis, G., Zotarelli, L., Fraisse, C., Zurweller, B. A., ... Rowland, D. L. (2016). Smartphone apps for irrigation scheduling. Trans. ASABE, 59(1), 291-301. https://doi.org/10.13031/trans.59.11158

Migliaccio, K. W., Schaffer, B., Crane, J. H., \& Davies, F. S. (2010). Plant response to evapotranspiration and soil water sensor irrigation scheduling methods for papaya production in south Florida. Agric. Water Mgmt., 97(10), 1452-1460. https://doi.org/10.1016/j.agwat.2010.04.012

Miller, G. A., Farahani, H. J., Hassell, R. L., Khalilian, A., Adelberg, J. W., \& Wells, C. E. (2014). Field evaluation and performance of capacitance probes for automated drip irrigation of watermelons. Agric. Water Mgmt., 131, 124-134. https://doi.org/10.1016/j.agwat.2013.09.012

Musick, J. T., \& Lamm, F. R. (1990). Preplant irrigation in the central and southern high plains: A review. Trans. ASAE, 33(6), 1835-1842. https://doi.org/10.13031/2013.31547 
NRC. (2002). Report of a workshop on predictability and limits-toprediction in hydrologic systems. Washington,, DC: National Research Council.

Nguyen, D. C., Ascough, J. C., Maier, H. R., Dandy, G. C., \& Andales, A. A. (2017). Optimization of irrigation scheduling using ant colony algorithms and an advanced cropping system model. Environ. Model. Softw., 97, 32-45. https://doi.org/10.1016/j.envsoft.2017.07.002

Oosterhuis, D. M., \& Bourland, F. M. (2008). COTMANTM crop management system. Fayetteville, AR: University of Arkansas, Division of Agriculture. Retrieved from https://www.cottoninc.com/wpcontent/uploads/2017/10/COTMAN-Manual-2008.pdf

O’Shaughnessy, S. A., Andrade, M. A., \& Evett, S. R. (2017). Using an integrated crop water stress index for irrigation scheduling of two corn hybrids in a semi-arid region. Irrig. Sci., 35(5), 451-467. https://doi.org/10.1007/s00271-017-0552-x

O’Shaughnessy, S. A., Evett, S. R., \& Colaizzi, P. D. (2015). Dynamic prescription maps for site-specific variable-rate irrigation of cotton. Agric. Water Mgmt., 159, 123-138. https://doi.org/10.1016/j.agwat.2015.06.001

O'Shaughnessy, S. A., Evett, S. R., Colaizzi, P. D., \& Howell, T. A. (2012). Grain sorghum response to irrigation scheduling with the time-temperature threshold method and deficit irrigation levels. Trans. ASABE, 55(2), 451-461. https://doi.org/10.13031/2013.41395

Osroosh, Y., Khot, L. R., \& Peters, R. T. (2018). Economical thermal-RGB imaging system for monitoring agricultural crops. Comput. Electron. Agric., 147, 34-43. https://doi.org/10.1016/j.compag.2018.02.018

Peters, R. T., Hoogenboom, G., \& Hill, S. (2013). Simplified irrigation scheduling on a smartphone or web browser. Technical paper. Proc. Irrigation Show. Fairfax, VA: Irrigation Association.

Raes, D., Steduto, P., Hsiao, T. C., \& Fereres, E. (2012). Chapter 3: Calculation procedures. In Reference manual AquaCrop ver. 4. Rome, Italy: United Nations FAO, Land and Water Division.

Rogers, D. H. (2012). Introducing the web-based version of KANSCHED: An ET-based irrigation scheduling tool. Proc. 24th Annual Central Plains Irrigation Conf. Colby, KS: Central Plains Irrigation Association.

Rudnick, D. R., Djaman, K., \& Irmak, S. (2015). Performance analysis of capacitance and electrical resistance-type soil moisture sensors in a silt loam soil. Trans. ASABE, 58(3), 649665. https://doi.org/10.13031/trans.58.10761

Rudnick, D. R., Stockton, M., Taghvaeian, S., Warren, J. G., Dukes, M. D., Kremen, A., ..., Amosson, S. H. (2020). Innovative extension methods in the U.S. to promote irrigation water management. Trans. ASABE, 63(5), https://doi.org/10.13031/trans.13929", in press.

Sanchez, L. A., Sams, B., Alsina, M. M., Hinds, N., Klein, L. J., \& Dokoozlian, N. (2017). Improving vineyard water use efficiency and yield with variable-rate irrigation in California. Adv. Anim. Biosci., 8(2), 574-577. https://doi.org/10.1017/S2040470017000772

Saseendran, S. A., Ahuja, L. R., Ma, L., Trout, T. J., McMaster, G. S., Nielsen, D. C., ... Fang, Q. X. (2015). Developing and normalizing average corn crop water production functions across years and locations using a system model. Agric. Water Mgmt., 157, 65-77. https://doi.org/10.1016/j.agwat.2014.09.002

Schwartz, R. C., Evett, S. R., Anderson, S. K., \& Anderson, D. J. (2016). Evaluation of a direct-coupled time-domain reflectometry for determination of soil water content and bulk electrical conductivity. Vadose Zone J., 15(1). https://doi.org/10.2136/vzj2015.08.0115
Shackel, K., Fulton, A., Lampinen, B., \& Matsumoto, N. (2018a). Evaluating physiological indicators for early-season water management in walnut. Davis, CA: University of California, Department of Agriculture and Natural Resources. Retrieved from

https:/ucanr.edu/sites/cawalnut/showyears/2018/?repository=10 $6864 \& \mathrm{a}=177625$

Shackel, K., Volkov, V., Santiago, M., Strook, A., \& Lakso, A. (2018b). Micro-tensiometer sensor for continuous stem water potential in grapevines. Davis, CA: American Society for Enology and Viticulture. Retrieved from

http://www.asev.org/abstract/micro-tensiometer-sensorcontinuous-monitoring-stem-water-potential-grapevines

Shahdany, S. H., Taghvaeian, S., Maestre, J. M., \& Firoozfar, A. R. (2019). Developing a centralized automatic control system to increase flexibility of water delivery within predictable and unpredictable irrigation water demands. Comput. Electron. Agric., 163, 104862. https://doi.org/10.1016/j.compag.2019.104862

Sharda, V., Gowda, P. H., Marek, G., Kisekka, I., Ray, C., \& Adhikari, P. (2019). Simulating the impacts of irrigation levels on soybean production in Texas High Plains to manage diminishing groundwater levels. JAWRA, 55(1), 56-69. https://doi.org/10.1111/1752-1688.12720

Shelia, V., Šimůnek, J., Boote, K., \& Hoogenbooom, G. (2018). Coupling DSSAT and HYDRUS-1D for simulations of soil water dynamics in the soil-plant-atmosphere system. J. Hydrol. Hydromech., 66(2), 232-245. https://doi.org/10.1515/johh-20170055

Singh, J., Lo, T., Rudnick, D. R., Dorr, T. J., Burr, C. A., Werle, R., ... Muñoz-Arriola, F. (2018). Performance assessment of factory and field calibrations for electromagnetic sensors in a loam soil. Agric. Water Mgmt., 196, 87-98. https://doi.org/10.1016/j.agwat.2017.10.020

Soulis, K. X., \& Elmaloglou, S. (2018). Optimum soil water content sensors placement for surface drip irrigation scheduling in layered soils. Comput. Electron. Agric., 152, 1-8. https://doi.org/10.1016/j.compag.2018.06.052

Steiner, J. L., Briske, D. D., Brown, D. P., \& Rottler, C. M. (2018). Vulnerability of southern plains agriculture to climate change. Climatic Change, 146(1), 201-218. https://doi.org/10.1007/s10584-017-1965-5

Stewart, W. C., Fulton, A., Krueger, W. H., Lampinen, B. D., \& Shackel, K. A. (2011). Regulated deficit irrigation reduces water use of almonds without affecting yield. California Agric., 65(2), 90-95. https://doi.org/10.3733/ca.v065n02p90

Stone, K. C., Bauer, P. J., \& Sigua, G. C. (2016). Irrigation management using an expert system, soil water potentials, and vegetative indices for spatial applications. Trans. ASABE, 59(3), 941-948. https://doi.org/10.13031/trans.59.11550

Stone, K., Bauer, P., O'Shaughnessy, S., Andrade, M., \& Evett, S. (2019). A variable-rate irrigation decision support system for corn in the U.S. eastern coastal plain. In Precision agriculture ' 19 (pp. 673-679). Wageningen, The Netherlands: Wageningen Academic. https://doi.org/10.3920/978-90-8686-888-9_83

Sui, R. (2017). Irrigation scheduling using soil moisture sensors. $J$. Agric. Sci., 10(1). https://doi.org/10.5539/jas.v10n1p1

Sui, R., \& Baggard, J. (2015). Wireless sensor network for monitoring soil moisture and weather conditions. Appl. Eng. Agric., 31(2), 193-200. https://doi.org/10.13031/aea.31.10694

Sui, R., O'Shaughnessy, S. A., Evett, S. R., \& Andrade, M. A. (2020). Evaluation of a decision support system for variable-rate irrigation in a humid region. Trans. ASABE, 63(5), https://doi.org/10.13031/trans.13904", in press. 
Sui, R., Pringle, H. C., \& Barnes, E. M. (2019). Soil moisture sensor test with Mississippi Delta soils. Trans. ASABE, 62(2), 363-370. https://doi.org/10.13031/trans.12886

Sun, L., Yang, H. S., Hu, J., Porter, D., Marek, T., \& Hillyer, C. (2017). Reinforcement learning control for water-efficient agricultural irrigation. Proc. IEEE Intl. Symp. on Parallel and Distributed Processing with Applications and IEEE Intl. Conf. on Ubiquitous Computing and Communications (ISPA/IUCC) (pp. 1334-1341). Piscataway, NJ: IEEE. https://doi.org/10.1109/ISPA/IUCC.2017.00203

Susha Lekshmi, S. U., Singh, D. N., \& Shojaei Baghini, M. (2014). A critical review of soil moisture measurement. Measurement, 54, 92-105. https://doi.org/10.1016/j.measurement.2014.04.007

Taghvaeian, S., Comas, L., DeJonge, K. C., \& Trout, T. J. (2014). Conventional and simplified canopy temperature indices predict water stress in sunflower. Agric. Water Mgmt., 144, 69-80. https://doi.org/10.1016/j.agwat.2014.06.003

Thorp, K. R., Hunsaker, D. J., \& French, A. N. (2010). Assimilating leaf area index estimates from remote sensing into the simulations of a cropping systems model. Trans. ASABE, 53(1), 251-262. https://doi.org/10.13031/2013.29490

Tooker, J., Dong, J., Vuran, M. C., \& Irmak, S. (2012). Connecting soil to the cloud: A wireless underground sensor network testbed. Proc. 9th Annual IEEE Comm. Society Conf. on Sensor, Mesh, and Ad Hoc Comm. and Networks (SECON) (pp. 79-81). Piscataway, NJ: IEEE.

https://doi.org/10.1109/SECON.2012.6275848

Torrion, J. A., \& Stougaard, R. N. (2017). Impacts and limits of irrigation water management on wheat yield and quality. Crop Sci., 57(6), 3239-3251. https://doi.org/10.2135/cropsci2016.12.1032

Upchurch, D. R., Wanjura, D. F., Burke, J. J., \& Mahan, J. R. (1996). U.S. Patent No. 5,539,637.

USDA. (2014). 2013 Farm and ranch irrigation survey. Washington, DC: USDA National Agricultural Statistics Service. Retrieved from https://www.nass.usda.gov/Surveys/Guide_to_NASS_Surveys/F arm_and_Ranch_Irrigation/index.php

USDA. (2019). 2018 Irrigation and water management survey. Washington, DC: USDA National Agricultural Statistics Service. Retrieved from https://www.nass.usda.gov/Surveys/Guide_to_NASS_Surveys/F arm_and_Ranch_Irrigation/index.php

USDA. (2020). Web soil survey. Washington, DC: USDA Natural Resources Conservation Service. Retrieved from https://websoilsurvey.nrcs.usda.gov/

Varble, J. L., \& Chávez, J. L. (2011). Performance evaluation and calibration of soil water content and potential sensors for agricultural soils in eastern Colorado. Agric. Water Mgmt., 101(1), 93-106. https://doi.org/10.1016/j.agwat.2011.09.007

Vaz, C. M., Jones, S., Meding, M., \& Tuller, M. (2013). Evaluation of standard calibration functions for eight electromagnetic soil moisture sensors. Vadose Zone J., 12(2). https://doi.org/10.2136/vzj2012.0160

Vellidis, G., Liakos, V., Andreis, J. H., Perry, C. D., Porter, W. M., Barnes, E. M., ... Migliaccio, K. W. (2016). Development and assessment of a smartphone application for irrigation scheduling in cotton. Comput. Electron. Agric., 127, 249-259. https://doi.org/10.1016/j.compag.2016.06.021

Vellidis, G., Tucker, M., Perry, C., Reckford, D., Butts, C., Henry, H., ... Edwards, W. (2013). A soil moisture sensor-based variable-rate irrigation scheduling system. In Precision agriculture '13 (pp. 713-720). Wageningen, The Netherlands: Wageningen Academic.

Vories, E. D., Greene, J. K., Teague, T. G., Stewart, J. H., Phipps, B. J., Pringle, H. C., ... Griffin, T. W. (2011). Determining the optimum timing for the final furrow irrigation on mid-south cotton. Appl. Eng. Agric., 27(5), 737-745. https://doi.org/10.13031/2013.39574

Vories, E., O'Shaughnessy, S., \& Andrade, M. (2019). Comparison of precision and conventional irrigation management of cotton. In Precision agriculture '19 (pp. 695-702). Wageningen, The Netherlands: Wageningen Academic. https://doi.org/10.3920/978-90-8686-888-9 86

Vuran, M. C., Salam, A., Wong, R., \& Irmak, S. (2018). Internet of underground things in precision agriculture: Architecture and technology aspects. Ad Hoc Networks, 81, 160-173. https://doi.org/10.1016/j.adhoc.2018.07.017

Wanjura, D. F., Upchurch, D. R., \& Mahan, J. R. (1992). Automated irrigation based on threshold canopy temperature. Trans. ASAE, 35(1), 153-159. https://doi.org/10.13031/2013.28582

Wanjura, D. F., Upchurch, D. R., \& Mahan, J. R. (1995). Control of irrigation scheduling using temperature-time thresholds. Trans. ASAE, 38(2), 403-409. https://doi.org/10.13031/2013.27846

Wibowo, R. P., Hendricks, N. P., Kisekka, I., \& Araya, A. (2017). Using a crop simulation model to understand the impact of risk aversion on optimal irrigation management. Trans. ASABE, 60(6), 2111-2122. https://doi.org/10.13031/trans.12320

Workneh, F., O’Shaughnessy, S., Evett, S., \& Rush, C. M. (2017). Relationships between early wheat streak mosaic severity levels and grain yield: Implications for management decisions. Plant Disease, 101(9), 1621-1626. https://doi.org/10.1094/pdis-02-170176-re

Yang, Y., Sun, L., Hu, J., Porter, D., Marek, T., \& Hillyer, C. (2017). A reliable soil moisture sensing methodology for agricultural irrigation. Proc. IEEE Intl. Symp. on Parallel and Distributed Processing with Applications and IEEE Intl. Conf. on Ubiquitous Computing and Communications (ISPA/IUCC) (pp. 1342-1349). Piscataway, NJ: IEEE. https://doi.org/10.1109/ISPA/IUCC.2017.00204

Yaron, D., \& Bresler, E. (1983). Economic analysis of on-farm irrigation using response functions of crops. In D. Hillel (Ed.), Advances in irrigation (Vol. 2, pp. 223-255). Cambridge, MA: Elsevier. https://doi.org/10.1016/B978-0-12-024302-0.50013-8

Zhu, Y., Irmak, S., Jhala, A. J., Vuran, M. C., \& Diotto, A. (2019). Time-domain and frequency-domain reflectometry type soil moisture sensor performance and soil temperature effects in fine- and coarse-textured soils. Appl. Eng. Agric., 35(2), 117134. https://doi.org/10.13031/aea.12908

Zotarelli, L., Dukes, M. D., Scholberg, J. M., Femminella, K., \& Munoz-Carpena, R. (2011). Irrigation scheduling for green bell peppers using capacitance soil moisture sensors. J. Irrig. Drain. Eng., 137(2), 73-81. https://doi.org/10.1061/(ASCE)IR.19434774.0000281 